\title{
MYCBP2 wt Allele
}

National Cancer Institute

\section{Source}

National Cancer Institute. MYCBP2 wt Allele. NCI Thesaurus. Code C88942.

Human MYCBP2 wild-type allele is located in the vicinity of $13 q 22$ and is approximately $282 \mathrm{~kb}$ in length. This allele, which encodes probable E3 ubiquitin-protein lig ase MYCBP2 protein, may be involved in the modulation of both transcription and protein ubiquitination. 